\title{
Simulated hydrologic response to projected changes in precipitation and temperature in the Congo River basin
}

\author{
Noel Aloysius ${ }^{1, \mathrm{a}}$ and James Saiers ${ }^{1}$ \\ ${ }^{1}$ School of Forestry and Environmental Studies, Yale University, New Haven, CT, USA \\ ${ }^{a}$ now at: Department of Food, Agriculture \& Biological Engineering and Aquatic Ecology Laboratory, Department of \\ Evolution, Ecology and Organismal Biology, Ohio State University, Columbus, OH, USA \\ Correspondence to: Noel Aloysius (aloysius.1@osu.edu)
}

Received: 31 March 2016 - Discussion started: 6 April 2016

Revised: 16 June 2017 - Accepted: 25 June 2017 - Published: 16 August 2017

\begin{abstract}
Despite their global significance, the impacts of climate change on water resources and associated ecosystem services in the Congo River basin (CRB) have been understudied. Of particular need for decision makers is the availability of spatial and temporal variability of runoff projections. Here, with the aid of a spatially explicit hydrological model forced with precipitation and temperature projections from 25 global climate models (GCMs) under two greenhouse gas emission scenarios, we explore the variability in modeled runoff in the near future (2016-2035) and mid-century (2046-2065). We find that total runoff from the CRB is projected to increase by $5 \%$ [-9\%; 20\%] (mean - min and max - across model ensembles) over the next two decades and by $7 \%[-12 \% ; 24 \%]$ by mid-century. Projected changes in runoff from subwatersheds distributed within the CRB vary in magnitude and sign. Over the equatorial region and in parts of northern and southwestern CRB, most models project an overall increase in precipitation and, subsequently, runoff. A simulated decrease in precipitation leads to a decline in runoff from headwater regions located in the northeastern and southeastern CRB. Climate model selection plays an important role in future projections for both magnitude and direction of change. The multimodel ensemble approach reveals that precipitation and runoff changes under business-as-usual and avoided greenhouse gas emission scenarios (RCP8.5 vs. RCP4.5) are relatively similar in the near term but deviate in the midterm, which underscores the need for rapid action on climate change adaptation. Our assessment demonstrates the need to include uncertainties in climate model and emission scenario selection
\end{abstract}

during decision-making processes related to climate change mitigation and adaptation.

\section{Introduction}

Sustainable management of water resources for food production, supply of safe drinking water and provision of adequate sanitation present immense challenges in many countries of central Africa where the Congo River basin (CRB) is located (IPCC, 2014; UNEP, 2011; World Food Program, 2014). The economies of the nine countries that share the waters of the CRB are agriculture based (World Bank Group, 2014) and therefore are vulnerable to the impacts of climate change. Despite the abundant water and land resources and favorable climates, the basin countries are net importers of staple food grains and are far behind in achieving Millennium Development Goals (Bruinsma, 2003; Molden, 2007; UNEP, 2011). Appropriation of freshwater resources is expected to grow in the future as the CRB countries develop and expand their economies. At the same time, climate-change-related risks associated with water resources will also increase significantly (IPCC, 2014).

Historical, present and near-future greenhouse gas emissions in the CRB countries constitute a small fraction of global emissions; however, the impacts of climate change on water resources are expected to be severe due to the region's heavy reliance on natural resources (e.g., agriculture and forestry) (Collier et al., 2008; DeFries and Rosenzweig, 2010; Niang et al., 2014). The limited adaptation capacity in the $\mathrm{CRB}$ region is expected to cause water and food security 
challenges, which, in turn, can lead to ecosystem degradation and increased greenhouse gas emissions (Gibbs et al., 2010; IPCC, 2014; Malhi and Grace, 2000).

Strategies for addressing stresses on CRB water resources, including revival of rural economies (largely agriculture based), achieving millennium development goals and environmental conservation, would benefit from detailed information on the spatial and temporal variability of water balance components under different climate projection pathways. The effect of climate change on water resources can be investigated by incorporating climate change projections (e.g., precipitation and temperature) in simulation models that reliably represent the spatial and temporal variability of the CRB's hydrology. Such a framework could be applied to project changes in storage and runoff, and hence freshwater availability, under different socioeconomic pathways that affect climate trajectories.

A predictive framework of the CRB's hydrology is hindered by insufficient data and too few evaluations of models against available data (Beighley et al., 2011; Wohl et al., 2012). Basin-scale water budgets estimated from landbased and satellite-derived precipitation datasets reveal significantly different results, and modeled runoff shows only qualitative agreement with corresponding observations (Alsdorf et al., 2016; Beighley et al., 2011; Lee et al., 2011; Schuol et al., 2008). Tshimanga and Hughes $(2012,2014)$ recently developed a semi-distributed hydrologic model capable of simulating runoff in CRB. This work crucially identified approaches suitable for approximating runoff generation at the basin scale, although the spatial resolution of the model predictions is rather coarse for supporting regional water management and regional planning efforts. These regional planning efforts must take into account variability and uncertainties stemming from climate model selection and projected greenhouse gas emissions, but, with respect to freshwater runoff projections for the $\mathrm{CRB}$, these issues have been inadequately addressed.

The goals of this study are to (i) develop a spatially explicit hydrology model that uses downscaled output from general circulation models (GCMs) and is suitable for simulating the spatiotemporal variability of runoff in the CRB; (ii) test the ability of the hydrological model to reproduce historical data on CRB river discharges using both observed and GCM-simulated climate fields; (iii) quantify the sensitivity and uncertainty of modeled runoff projections to GCM selection; (iv) use the hydrologic model with individual GCMs and multi-GCM ensembles to project near-term (2016-2035) and midterm (2046-2065) changes in runoff for two greenhouse gas emission scenarios. We focus on the runoff projections because streams and rivers will serve as the primary sources of freshwater targeted for human appropriation (Burney et al., 2013; Molden, 2007).

\section{Materials and methods}

\subsection{The Congo River basin}

The Congo River basin, with a drainage area of 3.7 million $\mathrm{km}^{2}$, is the second largest river basin in the world by area and discharge (Fig. 1, average discharge of $\sim 41000 \mathrm{~m}^{3} \mathrm{~s}^{-1}$ ) (Runge, 2007). The basin extends from $9^{\circ} \mathrm{N}$ to $14^{\circ} \mathrm{S}$, while the longitudinal extent is 11 to $35^{\circ} \mathrm{E}$. A total of nine countries share the water resources of the basin. Nearly a third of the basin area lies north of the Equator. Due to its equatorial location, the basin experiences a range of climate regimes. The northern and southern parts have strong dry and wet seasons, while the equatorial region has a bimodal rainy season (Bultot and Griffiths, 1972). Much of the rain in the northern and southern CRB occurs in JuneJuly-August (JJA) and December-January-February (DJF), respectively. The primary and secondary rainy seasons in the equatorial region are September-October-November (SON) and March-April-May (MAM; see Bultot and Griffiths, 1972 and Fig. S1 in the Supplement). The mean annual precipitation is about $1500 \mathrm{~mm}$. Rainforests occupy nearly $45 \%$ of the basin and are minimally disturbed compared to the Amazon and southeast Asian forests (Gibbs et al., 2010; Nilsson et al., 2005). Grassland and savannah ecosystems, characterized by the presence of tall grasses, closed-canopy woodlands, low trees and shrubs, occupy another $45 \%$ (Adams et al., 1996; Bartholomé and Belward, 2005; Hansen et al., 2008; Laporte et al., 1998). Water bodies (lakes and wetlands) occupy nearly $2 \%$ of the area and are concentrated mostly in the southeastern and western equatorial parts of the CRB (Fig. 1). Soils of the CRB vary from highly weathered and leached Ultisols to Alfisols, Inceptisols and Oxisols (FAO/IIASA, 2009; Matungulu, 1992). Most soils are deep and well-drained, but they are very acidic, deficient in nutrients, have low capacity to supply potassium and exhibit a low cation exchange capacity (Matungulu, 1992).

In order to compare regional patterns in precipitation and runoff, we divided the basin into four regions: (i) northern Congo (NC), (ii) equatorial Congo (EQ), (iii) southwestern Congo (SW) and (iv) southeastern Congo (SE). The EQ region covers most of the rainforest. The $\mathrm{SE}$ region consists of numerous interconnected lakes and wetlands. Most of the CRB's population is concentrated in the NC, SE and SW regions (Center for International Earth Science Information Network (CIESIN) Columbia University et al., 2005).

\subsection{Hydrologic model for the Congo River basin}

We used the Soil Water Assessment Tool (SWAT), a physically based, semi-distributed watershed-scale model that operates at a daily time step (Arnold et al., 1998; Neitsch et al., 2011). The hydrological processes simulated include evapotranspiration, infiltration, surface and subsurface flows, 


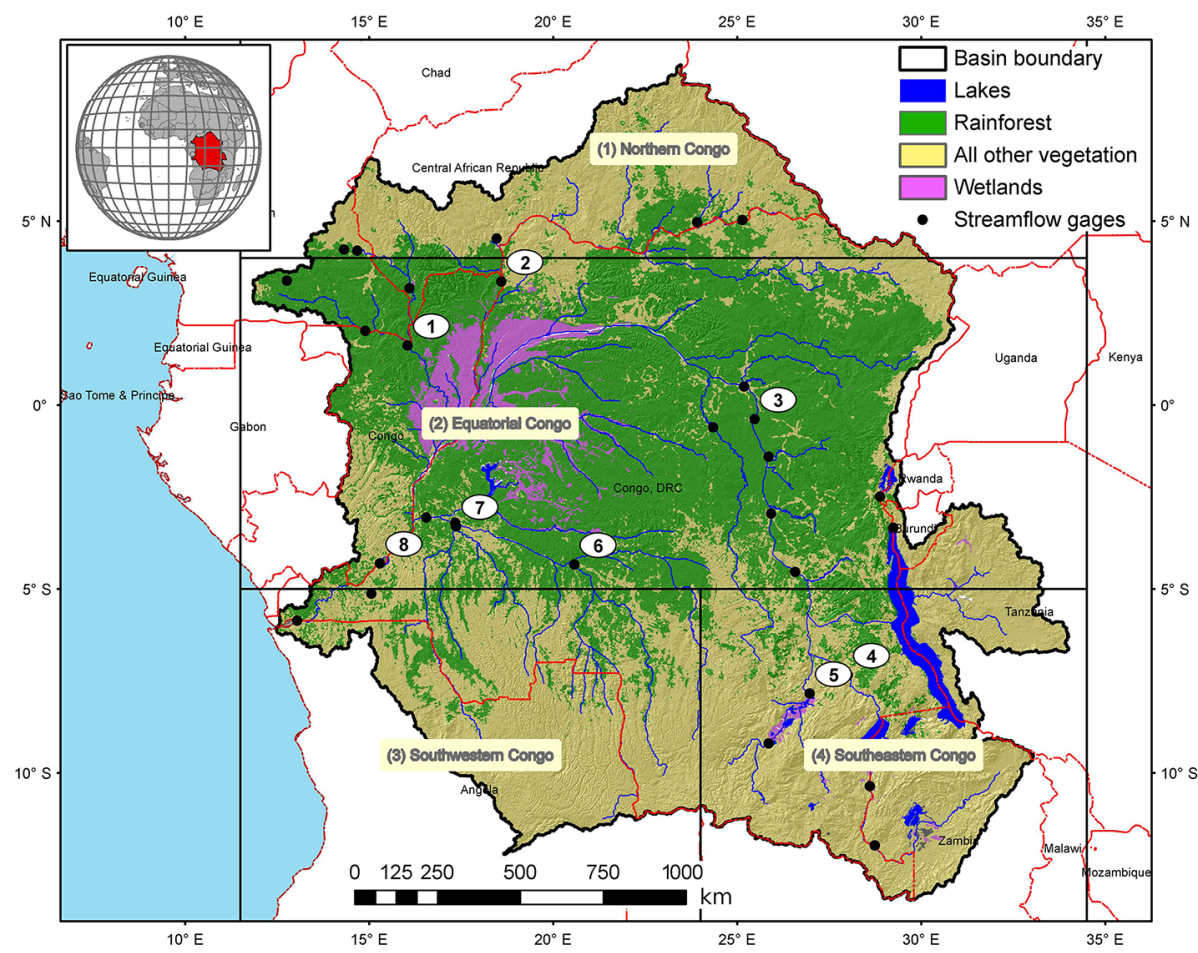

Figure 1. Congo River basin: the river basin boundary, the extent of the rainforest, locations of lakes and wetlands, and the locations of streamflow gages are shown. The "all other vegetation" category includes grasslands and savanna ecosystems, and all managed areas. Bartholomé and Belward (2005) provide further details on land cover in the Congo River basin.

streamflow routing and groundwater recharge. The model has been successfully employed to simulate river basin hydrology under a wide variety of conditions and to investigate climate change effects on water resources (Faramarzi et al., 2013; Krysanova and White, 2015; Schuol et al., 2008; Trambauer et al., 2013; van Griensven et al., 2012).

We delineated 1575 watersheds within the CRB based on topography (Lehner et al., 2008). Watershed elevations varied between 15 and $2700 \mathrm{~m}$ with a mean value of $680 \mathrm{~m}$ a.m.s.l. (above mean sea level). Each watershed consisted of one stream section, where near-surface groundwater flow and overland flow accumulated before being transmitted through the stream channel to the watershed outlet. Watersheds were further divided into hydrologic response units (HRUs) based on land cover (16 classes; Bartholomé and Belward, 2005), soils (150 types; FAO/IIASA, 2009) and topography. The runoff generated within each watershed was routed through the stream network using the variable storage routing method. The average watershed size and the number of HRUs within each watershed were $2300 \mathrm{~km}^{2}$ and 5 , respectively. We also included wetlands and lakes as natural storage structures that regulated the hydrological fluxes at different locations within CRB (Fig. 1). Detailed information was not available for the all the lakes; therefore, we incorporated the largest 16 lakes (Table S1 in the Supplement).
Simulated runoff, estimated for each HRU and aggregated at the watershed level, was generated via three pathways: overland flow, lateral subsurface flow through the soil zone and release from shallow groundwater storage. The curve number and a kinematic storage routing method were used to simulate overland and lateral subsurface flows, and a nonlinear storage-discharge relationship was used to simulate groundwater contribution (see Arnold et al., 1998; Neitsch et al., 2011 and the Supplement). A power-law relationship was employed to simulate the lake area-volume discharge (see the Supplement and Neitsch et al., 2011). The potential evapotranspiration was estimated using the temperaturebased Hargreaves method (Neitsch et al., 2011). The actual evapotranspiration was estimated based on available soil moisture and the evaporative demand (i.e., potential evapotranspiration) for the day. Additional details on model development and calibration are provided in the Supplement.

\subsection{Model simulation of historical hydrology with observed climate data}

We ran the hydrology model for the period 1950-2008. Estimates of observed daily precipitation, and minimum and maximum temperatures needed to calculate potential evapotranspiration were obtained from the Land Surface Hydrology Group at Princeton University (Sheffield et al., 2006). In addition, measured monthly streamflows were obtained at 30 
gage locations (Fig. 1) that had at least 10 years of records (Global Runoff Data Center, 2011; Lempicka, 1971; Vorosmarty et al., 1998).

The model was calibrated using observed streamflows for the period 1950-1957 at 20 locations. The locations of streamflow gages and time period were chosen such that they adequately captured climatic, land cover and topographic variability within the CRB. The number of model parameters estimated by calibration varied from 10 to 13 , depending on the location of flow gages (e.g., gages with lakes within their catchment area have more parameters). The calibration involved minimizing an objective function defined as the sum of squared errors between observed and simulated monthly average total discharge, baseflows (estimated by the baseflow separation method of Nathan and McMahon, 1990) and water yield. The Gauss-Marquardt-Levenberg algorithm, as implemented in a model-independent parameter estimation tool (Doherty, 2004), was used to adjust the fitted parameters and minimize the objective function. Parameter estimation was done in two stages. First, parameters for the watersheds in the upstream gages were estimated. Then, the parameters for the downstream gages were estimated. To test the calibrated model, simulated streamflows were compared to streamflows measured at the same 20 locations but during a period outside of calibration (i.e., 1958-2008), as well as at 10 additional locations that were not used in the calibration.

\subsection{Hydrologic simulations with simulated climate}

Historical climate simulations for the period 1950-2005 and climate projections to 2065 for two greenhouse gas emission scenarios (Representative Concentration Pathways RCPs), mid-range mitigation emission (RCP4.5) and high emission (RCP8.5), were used to drive the hydrologic model. The RCP4.5 scenario employs a range of technologies and policies that reduce greenhouse gas emissions and stabilize radiative forcing at $4.5 \mathrm{~W} \mathrm{~m}^{-2}$ by 2100 , whereas the RCP8.5 is a business-as-usual scenario, where greenhouse gas emissions continue to increase and radiative forcing rises above $8.5 \mathrm{~W} \mathrm{~m}^{-2}$ (Moss et al., 2010; Taylor et al., 2012). We used monthly precipitation and temperature outputs provided by 25 GCMs (Table 1) for the Fifth Assessment (CMIP5) of the Intergovernmental Panel on Climate Change (IPCC).

GCM outputs may exhibit biases in simulating regional climate. These biases, which are attributable to inadequate representation of physical processes by the models, prevent the direct use of GCM output in climate change studies (Randall et al., 2007; Salathé Jr. et al., 2007; Wood et al., 2004). Hydrological assessments that use GCM computations as input inherit the biases (Salathé Jr. et al., 2007; Teutschbein and Seibert, 2012). To mitigate this problem, we implemented a statistical method (Li et al., 2010) to bias correct the monthly historical precipitation and temperature data. In brief, the method employs a quantile-based mapping of cumulative probability density functions for monthly GCM outputs onto
Table 1. Global climate models whose outputs are used in this study. Further details about comparison of model outputs and key references for GCMs are given in Aloysius et al. (2016).

\begin{tabular}{ll}
\hline Model number & Model name \\
\hline M1 & ACCESS1-3 \\
M2 & bcc-csm1-1 \\
M3 & BNU-ESM \\
M4 & CanESM2 \\
M5 & CCSM4 \\
M6 & CESM1-CAM5 \\
M7 & CNRM-CM5 \\
M8 & CSIRO-Mk3-6-0 \\
M9 & EC-EARTH \\
M10 & FIO-ESM \\
M(11-13)* & GISS-E2-H* \\
M(14-16)* & GISS-E2-R* \\
M17 & HadGEM2-CC \\
M18 & HadGEM2-ES \\
M19 & INM-CM4 \\
M20 & IPSL-CM5A-LR \\
M21 & MIROC5 \\
M22 & MIROC-ESM \\
M23 & MPI-ESM-LR \\
M24 & MRI-CGCM3 \\
M25 & NorESM1-M \\
\hline These climate models provide outputs from \\
three different physics ensembles. We treat each \\
as a separate model. & \\
\hline
\end{tabular}

those of gridded observations in the historical period. The bias correction is extended to future projections as well. The observed data used in the modeling and bias correction have some limitations. That is, the number of precipitation gages decreased over the period from 1950 to 1990 , and the density of the gages is sparse compared to the size of the river basin (see Sect. 3.4 and the Supplement). However, we assumed that the available ground-based observations combined with satellite-based and reanalysis data adequately captured the spatiotemporal variability in precipitation. Studies by Munzimi et al. (2014) and Nicholson (2000) draw similar conclusions.

The simulated monthly precipitation and temperature values were temporally downscaled to daily values for use in the CRB hydrology model. We used the 3-hourly and monthly observed historical data developed for the Global Land Data Assimilation System (Rodell et al., 2004; Sheffield et al., 2006) and the bias-corrected monthly simulations to generate 3-hourly precipitation and temperature data, which were subsequently aggregated to obtain daily values (see the Supplement). The hydrological model was forced with the biascorrected and downscaled daily climate for the period 19502065. Due to the lack of information on the effect of $\mathrm{CO}_{2}$ on the 16 land cover classes simulated, the ambient $\mathrm{CO}_{2}$ concentration was maintained at $330 \mathrm{ppm}$ throughout the simu- 
lation period. A recent study suggests that, in tropical rainforest catchments, elevated $\mathrm{CO}_{2}$ has little impact on evapotranspiration but results in increased plant assimilation and light use efficiency (Yang et al., 2016).

A total of 50 projections (25 RCP4.5 and 25 RCP8.5 projections; see Table 1) were compiled and analyzed. Results of individual and multimodel means (unweighted average of all models (MMs) and an average of select models - SMs) for the near-term (2016-2035) and midterm (2046-2065) projections are presented.

Accessible flows (AFs), which exclude surface runoff associated the storm events, were estimated by applying a baseflow separation method described in Nathan and McMahon (1990).

\section{Results and discussion}

\subsection{Historical simulations}

Historical observations of average annual precipitation vary from $1100 \mathrm{~mm}$ in the southeastern portion of the CRB to $1600 \mathrm{~mm}$ in the CRB's equatorial region. We compared the GCM-simulated annual precipitation and its interannual variability during the historical period with observations from 30 locations within the CRB (Fig. 2). The simulated interannual variability among the climate models (vertical bars in Fig. 2) lies within the range of the observed variability (horizontal bars in Fig. 2). The linear regression slope of 1.16 $(p<0.001$; Fig. 2) between the annual observed and the multimodel means shows that bias-corrected precipitation is slightly overestimated but not significantly. Observations of seasonal precipitation are reproduced similarly well by the GCM models (Fig. S2 and Table S2). The good agreement between GCM-simulated and observed rainfall is expected given our bias correction of the GCM output.

We compared the simulated monthly runoff at 30 locations with observations (Fig. 3a and Table S3). The colored points compare observed mean annual runoff at the 30 gage locations with historical simulations (hydrological model forced with observed climate), while the vertical and horizontal bars show the modeled and observed interannual variability, respectively. The shades of colors (from light green to yellow and red) reveal the model's skill in simulating the monthly flows in the historical period. The Nash-Sutcliffe coefficient of efficiency (NSE), a measure of relative magnitude of residual variance compared to the monthly observed streamflow variance (Legates and McCabe Jr., 1999; Nash and Sutcliffe, 1970), varies between 0.01 and 0.86 (color scale in Fig. 3a). The NSE can range from negative infinity to 1 , with values between 0.5 and 1 considered satisfactory (Moriasi et al., 2007). A total of 17 of the 30 gages show NSE greater than or equal to 0.5. Higher NSE values at locations on both sides of the Equator, particularly at major tributaries (NSE 0.60, gages 1 to 8 in Figs. 1 and S3) suggest that the model re-

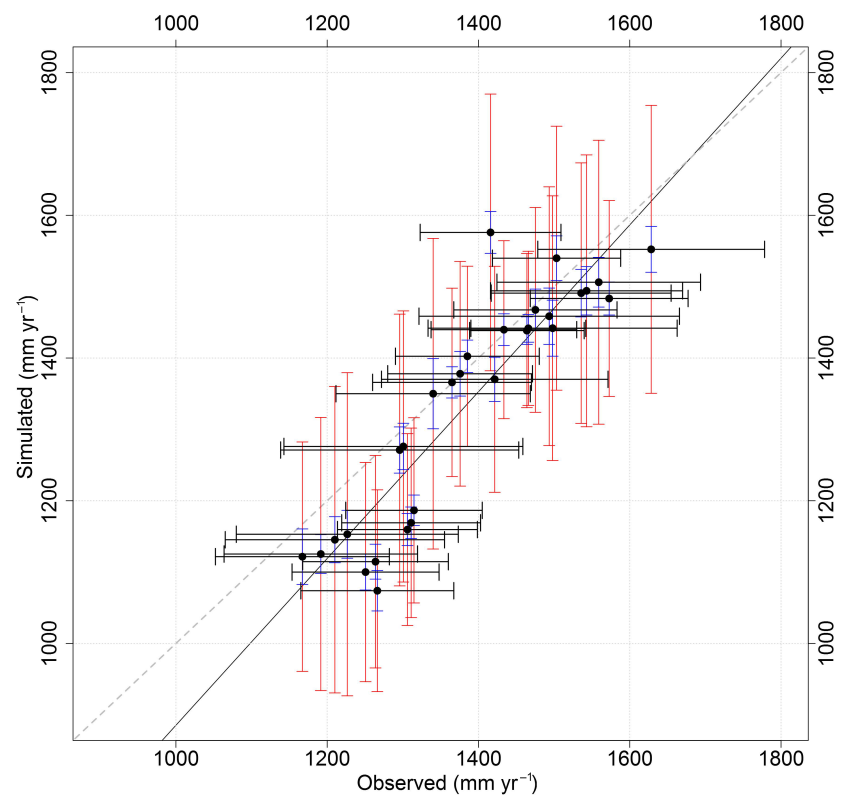

Figure 2. Comparison of observed and bias-corrected GCMsimulated average annual precipitation for 30 catchments with streamflow gages (shown in Fig. 1) in the historical period (1950 2005). The $y$-axis values are statistically downscaled GCMsimulated precipitation. Black dots compare multimodel means with observed precipitation, black horizontal bars show observed interannual variability $( \pm 1 \mathrm{SD})$ and red (blue) vertical bars show maximum (minimum) range of modeled interannual variability $( \pm 1 \mathrm{SD})$ within the 25 climate model outputs. The black line is the linear regression fit between observed and multimodel mean of simulated precipitation $(y=1.16 \pm 0.204 x-283.4, p<0.001$, $\left.R^{2}=0.825\right)$; parameter bounds indicate the $95 \%$ confidence interval. The gray dashed line is the $1: 1$ line.

liably simulates streamflows under different climatic conditions. High NSE values also indicate that the seasonal and annual runoff simulations, including the interannual variability in the historical period, are in good agreement with observations. The catchment areas of the 30 gages vary between 5000 and $900000 \mathrm{~km}^{2}$ (excluding the last two downstream gages; Table S3) and encompass a range of land cover and climatic regions on both sides of the Equator; thus, the hydrology model exhibits reasonable skill in simulating runoff over a wide range of watershed conditions.

Comparison of modeled runoff forced with GCMsimulated and observed climate (Fig. 3b) reveals generally acceptable runoff simulations in the CRB. The black dots and red (blue) vertical bars in Fig. 3b show multimodel mean and maximum (minimum) range of interannual variability in the 25 historical GCM simulations. The results suggest that model-data agreement in precipitation translates to similarly acceptable runoff simulations.

Runoff patterns reflect seasonal rainfall that varies asymmetrically on either side of the Equator (see Fig. S1). For example, the observed peak runoff at streamflow gages 2 
(a)

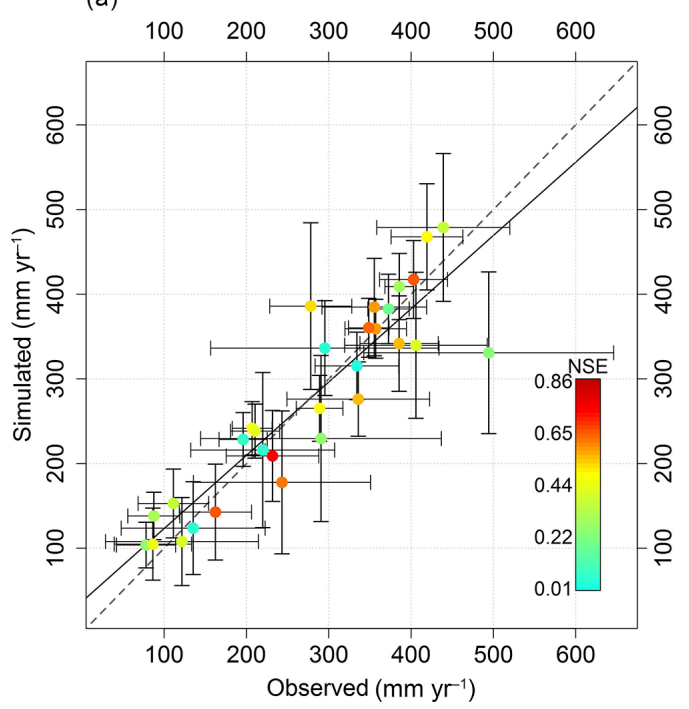

(b)

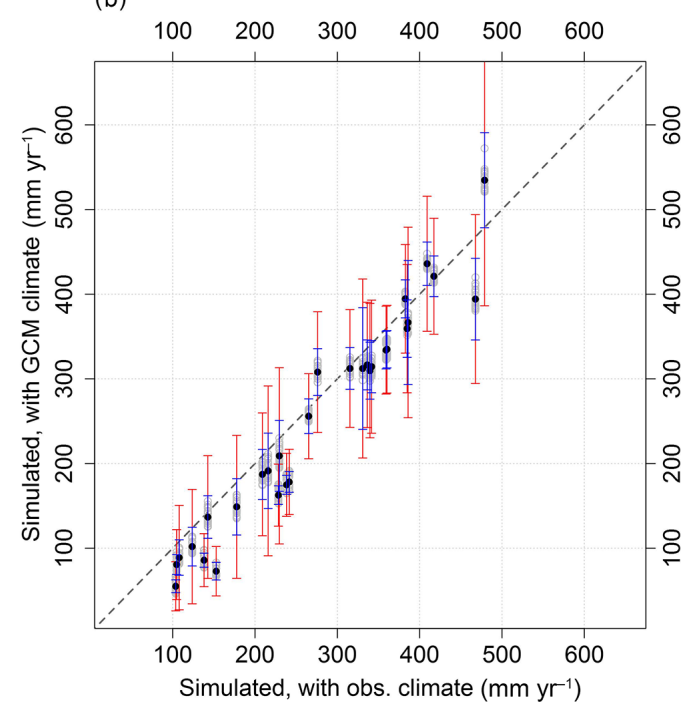

Figure 3. Comparison of observed and simulated annual runoff at the 30 streamflow gage locations (shown in Fig. 1). (a) Historical simulations with observed climate: the positions of the colored dots compare annual values of observed and simulated historical runoff; the dots' colors (see legend) show the Nash-Sutcliffe coefficient of efficiency (NSE) of observed vs. simulated monthly streamflows; and the black horizontal and vertical bars show observed and modeled interannual variability ( $\pm 1 \mathrm{SD})$, respectively. The black line indicates the linear regression fit between annual simulated and observed runoff ( $\left.y=0.865 \pm 0.158 x+36.63, p<0.001, R^{2}=0.82\right)$, parameter bounds indicate the $95 \%$ confidence interval. (b) Simulations in the historical period with GCM-simulated climate: black dots show the multimodel mean; red (blue) vertical bars show the modeled (forced with GCM-simulated historical climate) maximum (minimum) interannual variability ( \pm 1 SD) within the 25 simulations; and gray circles show the multiyear mean of individual GCM simulations. The gray dashed lines in (a) and (b) are the $1: 1$ lines. The GCM-simulated outputs are statistically downscaled and bias corrected.

and 6 located north and south of the Equator (see Fig. 1) occur near the end of the rainy seasons - during SeptemberOctober and March-April, respectively (Fig. 4). Augmented by flows from northern and southern tributaries (e.g., gages 1 , 2, 4 and 6) and by high precipitation in the tropical equatorial watersheds during the two wet seasons (MAM and SON), the main river flows (downstream of gage 3 in Fig. 1) show low variability (Fig. 4). Differences in streamflow variability between the main river and its tributaries are illustrated through comparison of the coefficient of variation, which equals only 0.23 at the basin outlet (gage 8), but is 0.77 and 0.40 along the northern tributary (gage 2) and southern tributary (gage 4), respectively.

Runoff in the northern (NC) and southern (SW and SE) watersheds is strongly seasonal with long dry seasons, but this is not the case in the equatorial region (Fig. 5). Average watershed runoff varies between 20 and $70 \mathrm{~mm}$ during dry seasons to $100-140 \mathrm{~mm}$ during wet seasons in the NC, $\mathrm{SW}$ and SE. In the equatorial region, seasonal runoff varies between 100 and $150 \mathrm{~mm}$ with the highest values in SON. Overall, the precipitation-runoff ratio is about 0.30 in the CRB. The AF that can be appropriated for human use, and hence excludes runoff associated with flood events, is about $70 \%$ of the total runoff.

\subsection{Future projections in precipitation and runoff}

\subsubsection{Precipitation}

Aloysius et al. (2016) showed that GCM projections of temperature generally increase under both emission scenarios, in line with the historical upward trend for Africa (Hulme et al., 2001); however, precipitation projections contain large uncertainties. The modeled near-term (2016-2035) precipitation projections in the $\mathrm{CRB}$ vary between -4 and $6 \%$ with a multimodel mean (MM) change of $1 \%$ under the two emission scenarios relative to the reference period (19862005). Regionally, the northern CRB shows the largest annual increase in precipitation, followed by the southwestern and equatorial regions. However, the intermodel variability is larger than the MM in all regions, indicating greater projection uncertainties in both emission scenarios (Table 2). The midterm (2046-2065) projections of annual precipitation vary between -5 and $9 \%$, with the MM of 1.7 and $2.1 \%$ for RCP4.5 and RCP8.5, respectively. More than $70 \%$ of the ensembles in both RCPs project an increase in annual precipitation in the CRB over the midterm. The multimodel mean of all ensembles that project an increase (decrease) in precipitation is $2.7 \%(-2.4 \%)$ for RCP4.5 and $4.0 \%(-2.9 \%)$ for RCP8.5.

The GCMs project considerable spatial and seasonal variations in precipitation (Table 2 and Fig. 6). However, the stan- 
Table 2. MM of projected changes in precipitation (\%) in the four regions within the Congo River basin (see Fig. 1) for the near term (20162035) and the midterm (2046-2065) relative to the reference period of 1986-2005. The regions are identified in Fig. 1. The standard deviation values across the 25 GCM simulations are provided in parenthesis. DJF: December-January-February, MAM: March-April-May, JJA: JuneJuly-August and SON: September-October-November.

\begin{tabular}{|c|c|c|c|c|c|c|c|c|}
\hline & \multicolumn{2}{|c|}{ Northern (NC) } & \multicolumn{2}{|c|}{ Equatorial (EQ) } & \multicolumn{2}{|c|}{ Southwestern (SW) } & \multicolumn{2}{|c|}{ Southeastern (SE) } \\
\hline & $\mathrm{RCP} 4.5$ & RCP8.5 & $\mathrm{RCP} 4.5$ & RCP8.5 & $\mathrm{RCP} 4.5$ & RCP8.5 & $\mathrm{RCP} 4.5$ & RCP8.5 \\
\hline \multicolumn{9}{|c|}{ Near future (2016-2035) } \\
\hline Annual & $1.6(3.0)$ & $1.3(2.9)$ & $1.3(2.9)$ & $1.1(2.7)$ & $1.3(2.3)$ & $1.5(2.6)$ & $-0.4(3.7)$ & $0.1(4.2)$ \\
\hline DJF & $3.3(13.3)$ & $5.4(21)$ & $2.0(4.9)$ & $1.4(4.7)$ & $1.6(3.2)$ & $1.8(4.0)$ & $-0.3(3.7)$ & $0.04(4.8)$ \\
\hline MAM & $1.4(4.5)$ & $1.1(3.7)$ & $0.5(2.9)$ & $0.8(2.8)$ & $1.5(4.2)$ & $2.5(5.2)$ & $-0.5(7.8)$ & $0.9(8.3)$ \\
\hline JJA & $1.3(3.3)$ & $0.4(4.2)$ & $1.3(4.2)$ & $1.3(4.7)$ & $-0.7(14.6)$ & $-0.3(15.7)$ & $19.6(32.0)$ & $18.7(31.6)$ \\
\hline SON & $2.3(4.6)$ & $2.3(4.7)$ & $1.7(4.1)$ & $1.1(4.0)$ & $0.9(3.6)$ & $0.2(3.8)$ & $-0.6(5.4)$ & $-1(4.8)$ \\
\hline \multicolumn{9}{|c|}{ Midterm (2046-2065) } \\
\hline Annual & $1.6(3.8)$ & $1.2(4.9)$ & $1.7(3.4)$ & $2.4(3.9)$ & $2.9(2.9)$ & $3.3(4.0)$ & $0.2(5.4)$ & $0.3(7.4)$ \\
\hline DJF & $1.1(15.2)$ & $3.9(18.8)$ & $3.5(6.3)$ & $5.3(9.4)$ & $4.8(5.1)$ & $5.4(7.4)$ & $1.5(6.4)$ & $1.4(9.6)$ \\
\hline MAM & $0.9(4.4)$ & $0.6(5.4)$ & $1.5(3.5)$ & $2.4(3.5)$ & $4.1(5.1)$ & $6.9(5.8)$ & $0.4(9.6)$ & $2(11.0)$ \\
\hline JJA & $0.6(4.3)$ & $0.1(5.5)$ & $0.7(5.8)$ & $2.2(7.3)$ & $-6.1(14.8)$ & $-5.9(19)$ & $6.7(30.6)$ & $9.7(32.0)$ \\
\hline SON & $3.4(6.2)$ & $2.9(7.3)$ & $1.3(4.0)$ & $0.6(4.1)$ & $-0.3(4.2)$ & $-2.5(4.6)$ & $-3.2(5.2)$ & $-4.6(5.8)$ \\
\hline
\end{tabular}

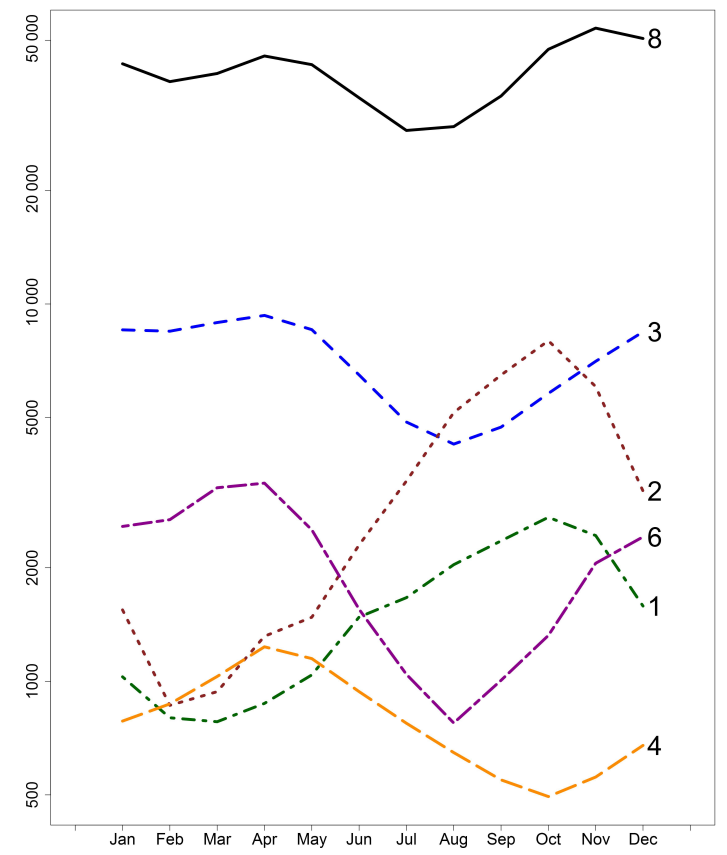

Figure 4. Mean monthly flows at selected tributaries in the CRB. Flows are in $\mathrm{m}^{3} \mathrm{~s}^{-1}$ and gage numbers are identified in Fig. 1. Monthly values are based on simulated flows (forced with observed precipitation) for the period 1950-2005.

dard deviation of annual and seasonal projections within the four regions exceed or are equal to the MM, indicating little agreement on the direction of change. The spatial patterns (Fig. 6), on the other hand, show regions where modeled projections strongly agree on increasing or decreasing precipi- tation. For example, decreasing precipitation is projected in most of the headwater catchments in the southern CRB and parts of northern CRB.

In general, the GCMs project decreasing precipitation in the driest parts of the southern CRB (mostly in the southeastern CRB but in portions of southwestern as well). Under the RCP8.5 scenario, parts of northeastern CRB also experience a reduction in precipitation in the near term (regions in Fig. 6 with fewer GCMs projecting an increase in precipitation). The areas of decreased precipitation shrink in the southeast and southwest in the midterm; however, drying expands in parts of northern CRB under the two emission scenarios. Most GCMs (14-20) project a precipitation increase outside of southeastern CRB.

Intermodel variability in precipitation projections are sensitive to seasons and climate region (Fig. 7a-d). At monthly scale, the northern and southern regions receive less than $50 \mathrm{~mm}$ of precipitation for at least 3 months, which persist in the future under both emission scenarios. The dry season is more prolonged in the southeast compared to the rest of the CRB. The intermodel variability is larger in the rainy seasons under RCP8.5 compared to RCP4.5. Larger variability under RCP8.5 highlights that GCMs may have limited skill in simulating precipitation under high greenhouse gas emissions.

\subsubsection{Runoff}

In general, modeled runoff increases, and its interannual variability within GCMs is larger during high flow periods compared to low flow periods, except in the equatorial region (Fig. 7e-h; see Fig. 1 for regions). The model projection uncertainty increases towards the middle of century, particularly under the RCP8.5 emission scenario. The temporal pat- 
(a) Northern (NC)

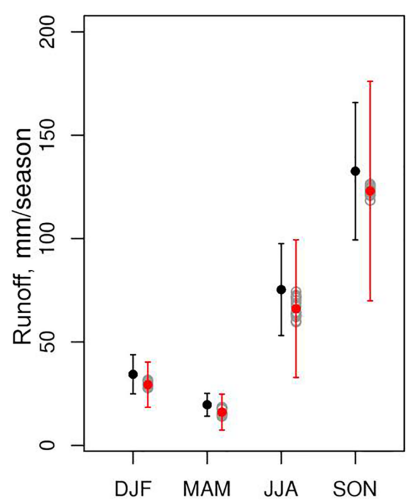

(C) Southwestern (SW)

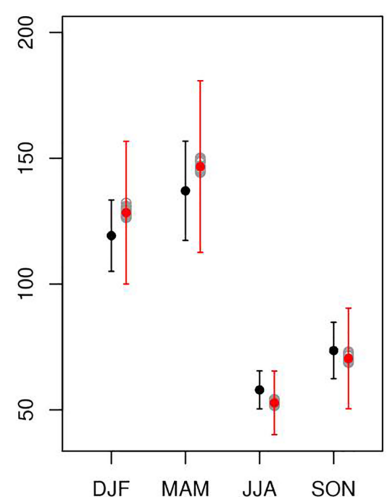

(a) Equatorial (EQ)

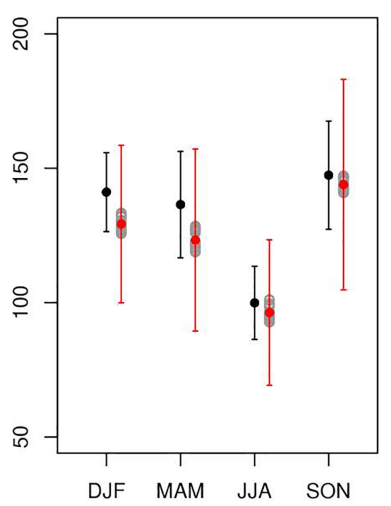

(d) Southeastern (SE)

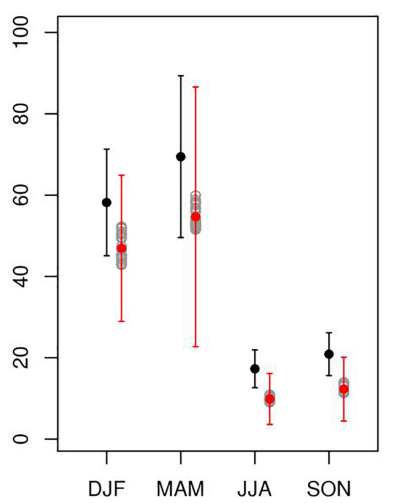

Figure 5. Seasonal variation in runoff in the (a) northern, (b) equatorial, (c) southwestern and (d) southeastern Congo River basin for the historical period (1950-2005). The seasonal total runoff are calculated for December-January-February (DJF), March-AprilMay (MAM), June-July-August (JJA) and September-OctoberNovember (SON). Black dots and vertical bars show the modeled interannual variability forced with observed climate, red dots show the MM forced with GCM-simulated climate, red vertical bars show the maximum range of interannual variability within the 25 models and the gray open circles show the means of individual models. The $y$-axis scale is different for each plot.

terns of runoff in the near term and midterm are similar to the precipitation patterns, but with a time lag. As with precipitation, the monthly runoff shows prolonged periods of low values in the northern and southern CRB in both projection periods. Parts of northern, southeastern and southwestern CRB also show reduced runoff projections relative to the reference period under both RCPs; these reductions are predominantly in the areas where fewer GCMs agree on the increase in modeled precipitation (see Fig. 6 and Tables S4 and S5). The area of decreasing runoff expands in the northern CRB under both emission scenarios in the midterm (see Fig. 6, which shows that more models agree on decreasing precipitation in parts of northern CRB that subsequently results in decreasing runoff). Although the northern and equatorial CRB show an overall increase in precipitation, the decrease in runoff in

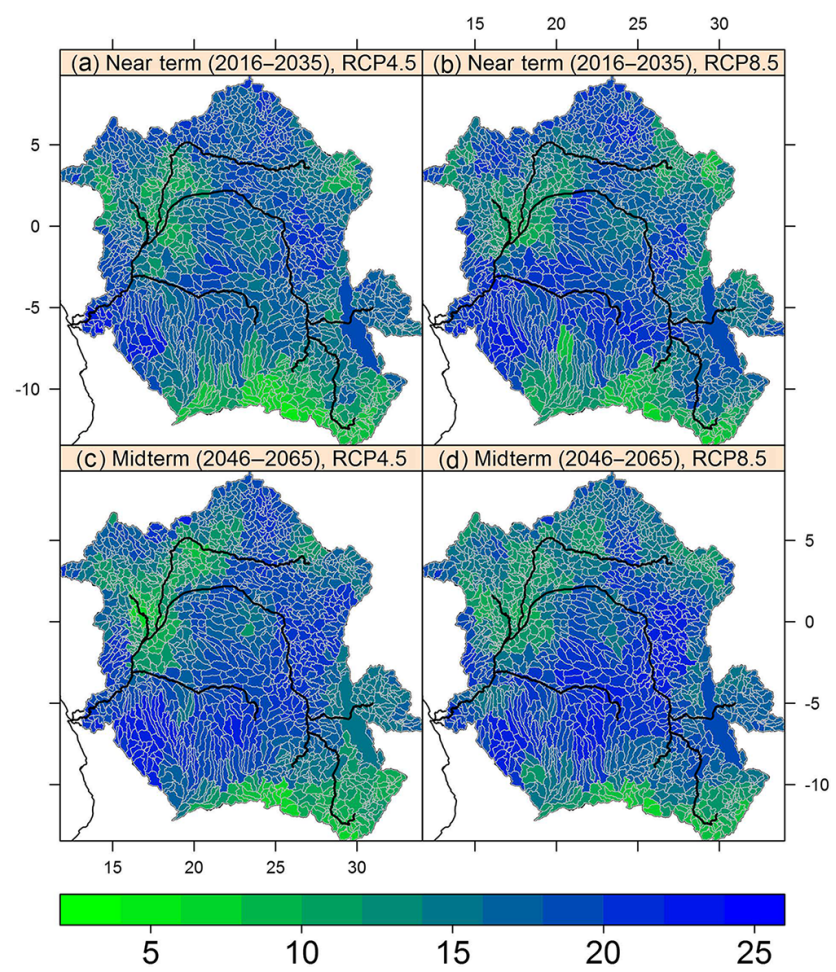

Figure 6. Number of climate model outputs projecting an increase in precipitation in the (a) near term (2016-2035) in RCP4.5; (b) near term in RCP8.5; (c) midterm (2046-2065) in RCP4.5; and (d) midterm in RCP8.5. The number of modeled precipitation outputs considered is 25. Main rivers and lakes are shown.

certain parts in the northern and equatorial CRB is caused by reduction in seasonal precipitation (e.g., JJA and SON; see Table S4). A larger reduction - up to $15 \%$ - in the southeastern CRB covering most of northern Zambia is due to an overall decrease in precipitation simulated by more than half of the GCMs (see Fig. 6).

The multimodel mean of total runoff from the CRB shows an increase of $5 \%( \pm 6 \%, 1 \mathrm{SD}, n=25)$ and $7 \%( \pm 8 \%)$ in the near term and midterm under both RCPs relative to the reference period (1986-2005). Annual runoff in the equatorial region, which receives the highest precipitation, is projected to increase by up to $5 \%( \pm 7 \%)$ in the near term to $6 \%( \pm 8 \%)$ and $7 \%( \pm 9 \%)$ in the midterm for RCP4.5 and RCP8.5, respectively. The increases are greater in the secondary rainy season (MAM) than the primary (SON; Fig. 7b and $\mathrm{f}$ ). The majority of the ensembles project an increase in monthly runoff within the equatorial CRB, with the RCP8.5 ensembles exhibiting larger variability (Fig. 7f).

Runoff that can be appropriated for human use is generated mostly in the northern, southeastern and southwestern CRB, which at present varies from $130 \mathrm{~mm} \mathrm{yr}^{-1}$ in the southeastern CRB to $250-400 \mathrm{~mm} \mathrm{yr}^{-1}$ in the northeastern and southwestern CRB. Runoff is projected to increase in all three of these regions. However, the intermodel variability is greater than 

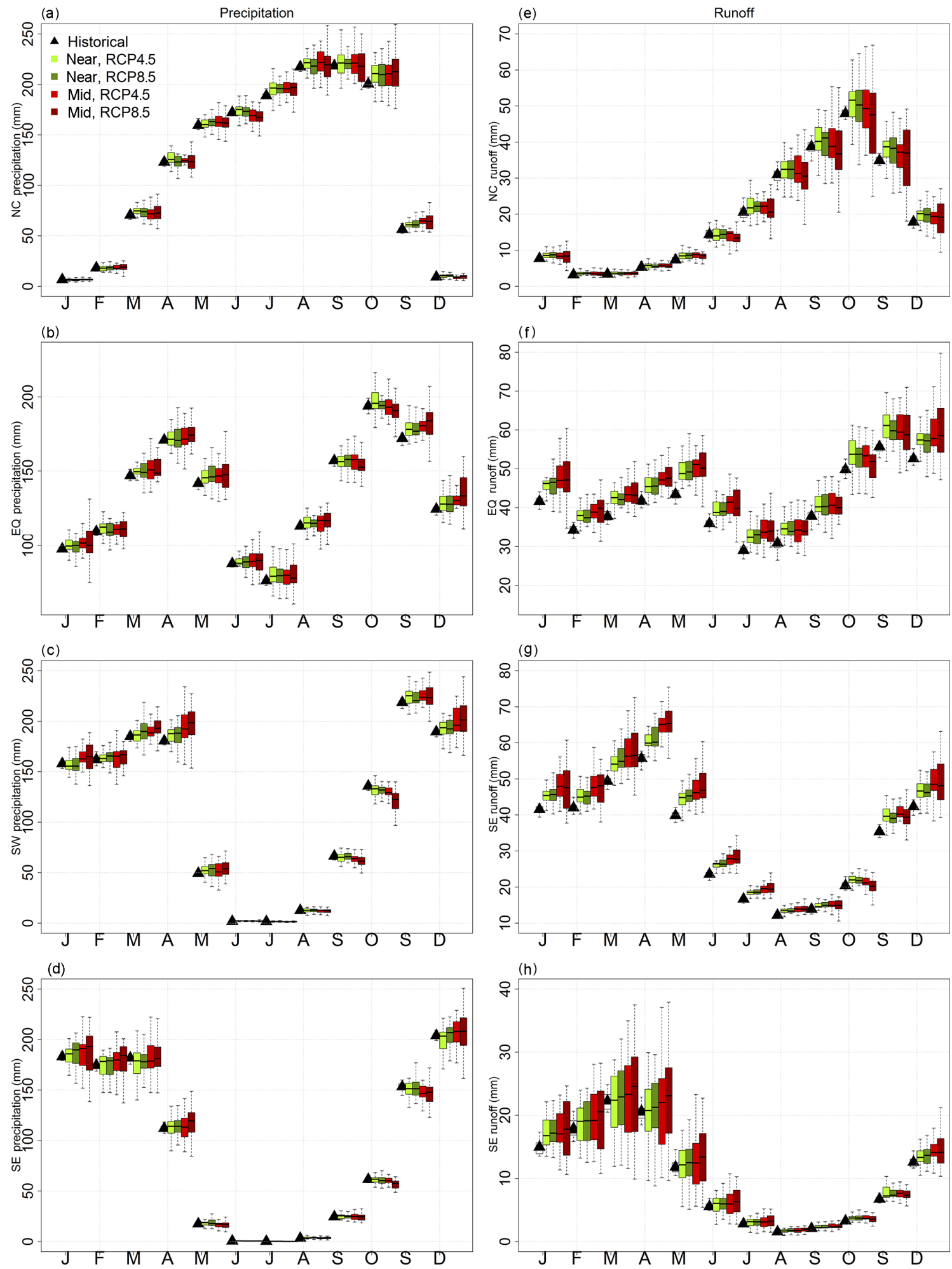

Figure 7. Monthly variation of precipitation (a-d) and runoff $(\mathbf{e}-\mathbf{h})$ in the four regions shown in Fig. 1. Box-and-whisker plots for each month show the intermodel variability for the historical period (black), near-term RCP4.5 (light green), near-term RCP8.5 (dark green), midterm RCP4.5 (red) and midterm RCP8.5 (brown). The upper and lower ends of the boxes show the 75th and 25th quartiles, the bar inside each box shows the median and the whiskers cover approximately $90 \%$ of the values. The multimodel mean values for the reference period are shown as triangles for clarity. All values are in millimeters per month. NC - northern, EQ - equatorial, SE - southeast and SW - southwest; see Fig. 1 for locations. "Mid" indicates the midterm and "near" indicates near term. 
(a) Northern (near)

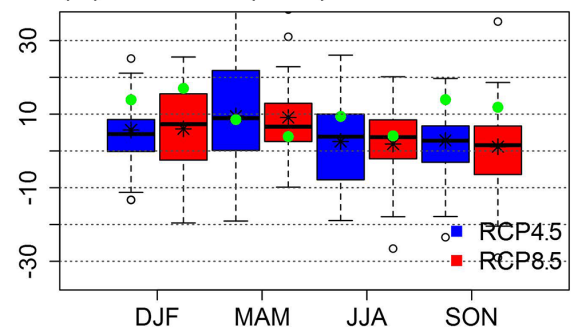

(c) Equatorial (near)

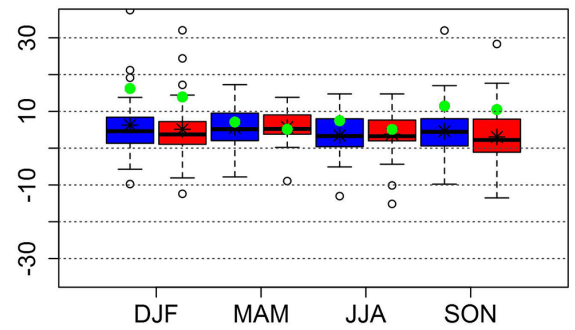

(e) Southwestern (near)

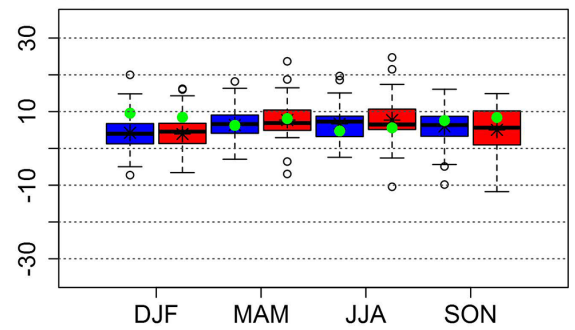

(g) Southeastern (near)

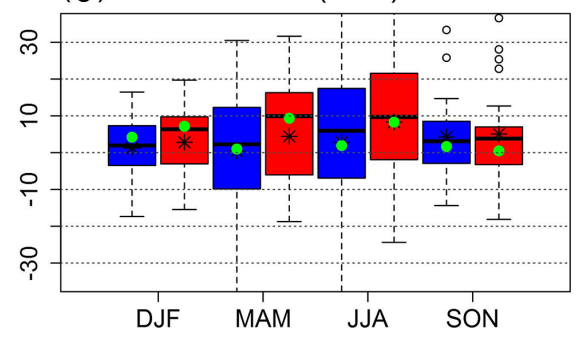

(b) Northern (mid)

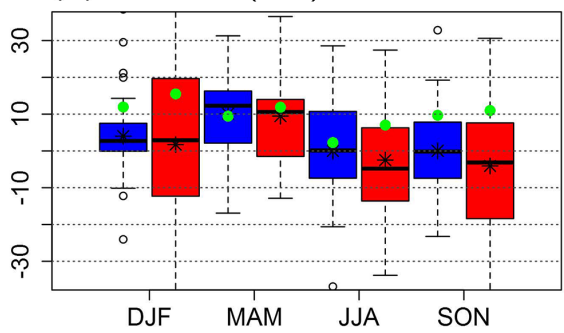

(d) Equatorial (mid)

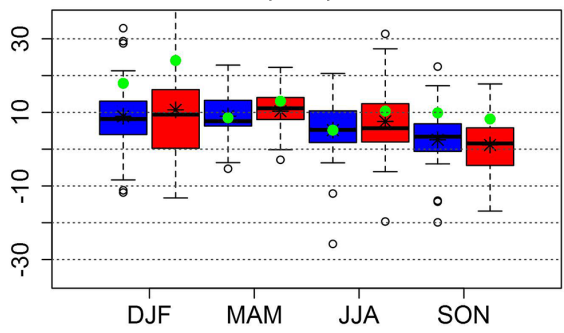

(f) Southwestern (mid)

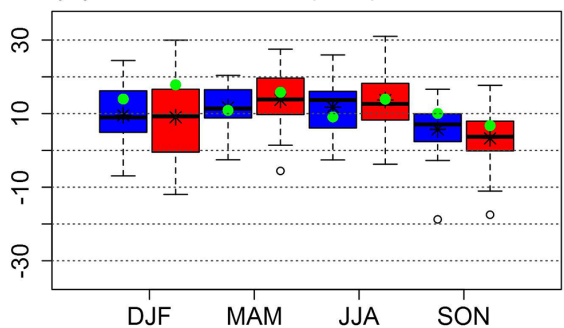

(h) Southeastern (mid)

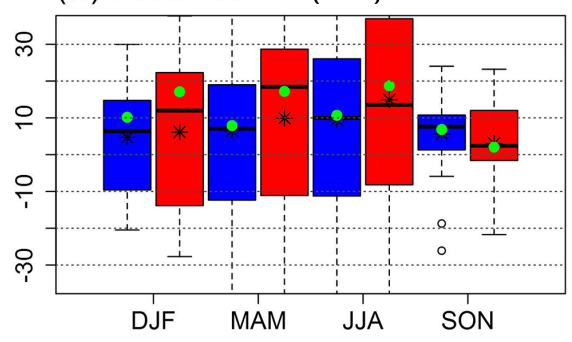

Figure 8. Seasonal runoff projections (as percent relative to the reference period 1986-2005) for the near-term (2016-2035) and midterm (2046-2065) projection periods for northern (a, b), equatorial (c, d), southwestern (e, f) and southeastern (g, h) regions. Boxes show the 25th and 75th percentiles, the horizontal line within the boxes show median value and the whiskers mark the 5th and 95th percentiles. The multimodel mean (asterisks) and the select-model mean (green dots) are also shown. The $y$-axis range is limited to show the smaller boxes. The $y$-axis values are in percentages. "Mid" indicates the midterm and "near" indicates near term.

twice the MM in nearly all the regions and during all four seasons (Fig. 8 and Table 3). In most cases, the largest uncertainties are in non-rainy seasons and under a high emission RCP8.5 scenario (e.g., DJF in the northern CRB; Fig. 8b, and JJA in the southeastern CRB; Fig. 8h).

\subsection{Variability in accessible flows}

Only part of the runoff may be appropriated for human use. In the CRB, the accessible runoff (AF), excluding runoff associated with flood events, is about $70 \%$. The AF is largely underutilized, but its appropriation is expected to increase in the future, mostly in the populated areas of northern, southwestern and southeastern CRB. We present the uncertainty associated with GCM and scenario selection by quantifying seasonal and intermodel variability in $\mathrm{AF}$ at eight major tributaries (identified in Fig. 1) that drain watersheds across a range of climatic regions on both sides of the Equator (Fig. 9). Modeled AF exhibits substantial intermodel spread in the near term and widens in the midterm (Fig. S4). The intermodel variability is larger during high flow periods compared to low flow periods. 
Table 3. MM of projected changes in runoff (\%) in the four regions within the Congo River basin for the near term (2016-2035) and the midterm (2046-2065) relative to the reference period of 1986-2005. The regions are identified in Fig. 1. The standard deviation values across the 25 GCM simulations are provided in parenthesis. The asterisks $\left({ }^{*}\right)$ show the degree of agreement that projected runoff is greater than 0 in more than $50 \%$ of the ensembles. DJF: December-January-February, MAM: March-April-May, JJA: June-July-August and SON: September-October-November.

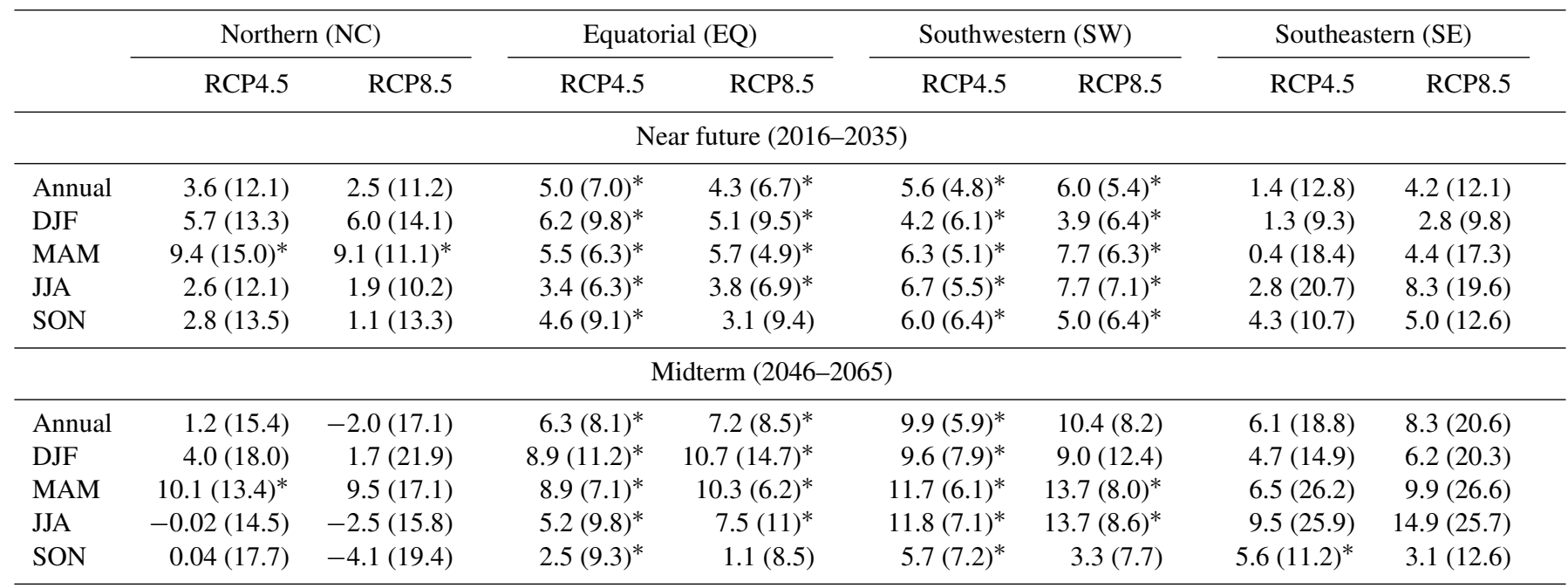
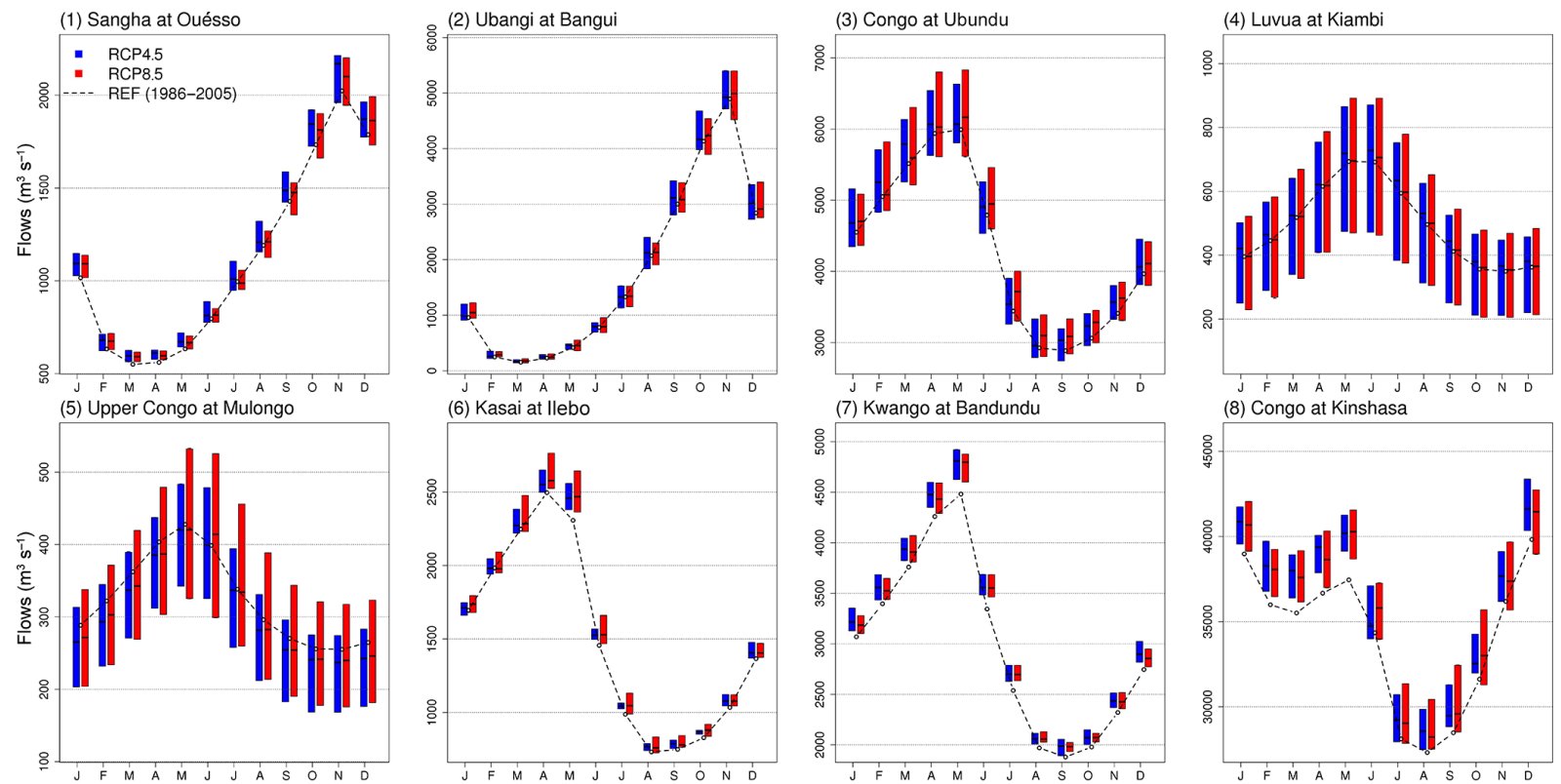

Figure 9. Accessible streamflow hydrographs in the near term at selected locations shown in Fig. 1a. Blue and red bars (RCP4.5 and RCP8.5, respectively) show the intermodel variability. The dotted black line shows the hydrograph in the reference period (1986-2005). Plot numbers 1-8 coincide with the gage numbers in Fig. 1.

Following the general pattern of increasing precipitation and runoff in the northern and southwestern watersheds, we find that AF increases with greater model agreement in tributaries that drain these watersheds (e.g., gages 1, 2 and 6 in Fig. 9). A closer look at tributaries in the northern and southwestern CRB reveals better agreement of increased AF during low flow periods compared to high flow periods (com- pare gages 1, 2, 6 and 7 in Fig. 9). In contrast, tributaries that drain southeastern watersheds exhibit greater variability in modeled AF with majority of the ensembles projecting a reduction (e.g., gages 4 and 5 in Fig. 7). Overall, the AF in the main tributary (gages 3 and 8 ) is projected to increase, partly due to the contributions from the northern and southwestern tributaries. The decrease in modeled precipitation and AF in 
the southeastern CRB appears to have a marginal effect on downstream flows in the main river.

The spatial and temporal variations in the projected $\mathrm{AF}$ have consequences for water resources development and management. For example, projections of increased AF near the proposed Grand Inga Hydropower Project (near gage 8; Showers, 2009) are robust compared to the large variations near the proposed transboundary water diversion in the southeast (near gage 5, Lund et al., 2007). Reductions in high and low flows in streams in the southeastern region will have implications for aquatic life, channel maintenance and lake and wetland flooding.

\subsection{Sources of uncertainty}

The sources of uncertainty encountered in this work can be broadly categorized into (i) observational uncertainty, particularly the sparse and declining network of precipitation and streamflow gages and (ii) model uncertainty, which in the GCMs includes model structure, model initialization, parameterization and climate sensitivity (i.e., the response of global temperature to a doubling of $\mathrm{CO}_{2}$ relative to pre-industrial levels). We used only one hydrological model, which is also a source of uncertainty. However, variation in climate signals between GCMs and emissions scenarios, particularly precipitation projections, may be a larger source of uncertainty than the choice of hydrology model (Thompson et al., 2014; Vetter et al., 2016).

The climate data used for bias correction and for historical hydrologic simulations have their own uncertainties. Gagebased, satellite-derived data and reanalysis outputs are used to develop the historical observations (Sheffield et al., 2006). Precipitation gages were more numerous at the beginning of the simulation period and declined in number toward the end of the 20th century (Mitchell and Jones, 2005; Washington et al., 2013). Available gage data varied both spatially and temporally (Figs. S5 and S6). For example, the equatorial region - nearly a third of CRB - had about 70 rain gages through the early 1990s, but only $10 \%$ of these were functioning by 2005 (Fig. S5). The southeastern and parts of northern CRB also had good rainfall-gage coverage, which has similarly decreased since the 1990s (Mitchell and Jones, 2005). However, satellite-based and sparsely distributed gage data have been used to demonstrate that spatiotemporal distribution of precipitation can be sufficiently described in the CRB region (Munzimi et al., 2014; Nicholson, 2000; Samba et al., 2008). We assume that, even with these limitations, the available historical data are adequate to model the hydrology of the CRB.

In addition to climate data, observed runoff data are another limitation that could restrict proper validation of hydrological models. However, we utilized a time period (19501959) when the CRB had maximum coverage of both precipitation and runoff data to calibrate and test the hydrology model (for example, see evidence in L'vovich, 1979). Where available, we used additional runoff data to further test model outputs during the historical period. The runoff gage locations are distributed within the CRB (see Fig. 1) such that they adequately capture climatic, land cover and topographic variability.

For future projections, the largest sources of uncertainty arise from the GCMs and emission scenarios. GCMs do not consistently capture observed rainfall seasonality and heavy rainfall in regions of the central CRB and in most cases do not show key features such as seasonality and heavy rainfall in regions of the central CRB (Aloysius et al., 2016; Washington et al., 2013). The biases in the GCM-simulated precipitation, particularly in the tropical regions, have been attributed to multiple factors including poorly resolved physical processes such as the mesoscale convection systems, inadequately resolved topography due to the coarse horizontal resolution and inadequate observations to constrain parameterization schemes. These limitations are unavoidable in the current set of CMIP5 projections. We assume that the combination of GCM outputs used in our work and the biascorrection method, which maintains key statistical properties in the original GCM outputs (see Aloysius et al., 2016; Li et al., 2010), adequately captures the uncertainties in GCM and emission scenarios. Based on monthly precipitation climatology, Aloysius et al. (2016) found no significant shift in seasonality in modeled future precipitation projections.

The range of projections presented here for the two emission scenarios also highlight the uncertainties planners would encounter when making climate-related decisions. For example, broader agreement on increase in runoff in parts of the CRB would help make robust decisions, whereas weaker agreement in the southern CRB calls for greater scrutiny of regional climate. Generally, the MM approach reduces the uncertainty because averaging tends to offset errors across models. However, one could also ask whether this approach would work with fewer models.

Washington et al. (2013) and Siam et al. (2013) presented evidence that evaluating atmospheric moisture flux (which is modulated by wind patterns and humidity) and soil water balance is a better way to diagnose GCM performance in datascarce regions like the CRB. Balas et al. (2007), Hirst and Hastenrath (1983) and Nicholson and Dezfuli (2013) have shown that sea surface temperature (SST) anomalies in the Atlantic and Indian ocean sectors could partly explain precipitation in the CRB region. Along the same lines, Aloysius et al. (2016) identified five models as suitable candidates. We examined this subset of GCM projections (M6, M7, M18, M23 and M24), which we refer to as the select model average, or SM (see Giorgetta et al., 2013; Good et al., 2012; Jungclaus et al., 2013; Meehl et al., 2013; Siam et al., 2013; Voldoire et al., 2012; Yukimoto et al., 2006 and Aloysius et al., 2016 for further comparison of GCM performance). By evaluating seasonal atmospheric moisture and soil water balance in 11 CMIP5 GCMs in the CRB and Nile River basin 
regions, Siam et al. (2013) identified M7, M18 and M24 as good candidates for climate change assessment.

Focusing on the northern, southeastern and southwestern $\mathrm{CRB}$, where human appropriation of runoff is expected to increase, we find that the projected increase of annual runoff in SM is more than that of MM (20 to $50 \%$ higher in the SM compared to MM). In addition, the extent of reduction in runoff in the south is concentrated in the southeastern upstream watersheds in both MM and SM, although the magnitude of decrease is smaller in SM (Tables S4 and S5).

From the viewpoint of water resources for human appropriation, the changes by seasons are also important. Future changes and uncertainties in modeled seasonal runoff averaged over the four regions are presented in Fig. 8. In comparison with the $\mathrm{CRB}$ projections, the uncertainties in subregions are larger. Nearly all the MM and SM projections show an increase in runoff in all the four seasons; however, there is substantial intermodel variability. The uncertainties increase under the high emission RCP8.5 scenario during the midcentury. Considering the southeastern region as an example, under the RCP8.5 emission scenario, uncertainties reported as 1 intermodel standard deviation in the midterm are \pm 20 , $\pm 27, \pm 26$ and $\pm 13 \%$, respectively, for DJF, MAM, JJA and SON seasons, and are greater than the MM and SM. Further, the deviation of uncertainty within the subregions of CRB increases under the high emission RCP8.5 scenario. For example, the intermodel projection ranges are larger in the northern and southeastern CRB (Fig. 8b and h) compared to the equatorial and southwestern CRB (Fig. 8d and f). Finally, the uncertainty assessment presented here represents climate model uncertainty arising from emission scenarios, different response to the same external forcing, different model structures and parameterization schemes. While these uncertainties in projections pose challenges for robust decisionmaking, they also provide insights into where further research might be most valuable.

\section{Conclusions}

From the point of view of climate change adaptation related to water resources, agriculture and ecosystem management, the challenge faced by CRB countries is recognizing the value of making timely decisions in the absence of complete knowledge. In some settings, climate change presents opportunities as well as threats in the CRB. The projected increases in accessible runoff imply new opportunities to meet increasing demands (e.g., drinking water, food production and sanitation), while the enhanced flood runoff would pose new challenges (e.g., flood protection and erosion control). On the other hand, water managers could face different challenges in the southeast where precipitation and runoff are projected to decrease.

GCM-related variability in regional climate projections could be constrained by a subset of models based on at- tributes that modulate large-scale circulations (see Knutti and Sedlacek, 2013; Masson and Knutti, 2011). This approach is particularly useful because regions like the CRB lack complete coverage of observational data but the mechanisms that moderate the climate system, particularly precipitation, are fairly well understood (Hastenrath, 1984; Nicholson and Grist, 2003; Washington et al., 2013). Yet, the span in rainfall predictions among the MM, SM and individual GCMs suggests that, despite the advances in climate modeling, significant uncertainties in precipitation projections for CRB persist.

Rather than providing a narrow pathway for decisionmaking, our results, for the first time for CRB, provide a framework to (i) assess implications under various climate model assumptions and uncertainties, (ii) characterize and expose vulnerabilities and (iii) provide ways to guide the search for impact-oriented and actionable policy alternatives, as emphasized by Weaver et al. (2013). Projections and associated uncertainties vary widely by region within the CRB, and therefore diverse but robust planning strategies might be advisable within the river basin. We emphasize that projections provided here could be considered as part of the process of incorporating multiple stressors into climate change adaptation and engaging stakeholders in the decision-making process.

Data availability. Historical observed climate data, described in Sheffield et al. (2006), are available at http://hydrology.princeton. edu/data/pgf/Readme.txt. Details of bias-corrected future climate data are provided in Aloysius et al. (2016). References for observed streamflow data are (i) Global Runoff Data Center, 2011 (http: //www.bafg.de/GRDC/EN/Home/homepage_node.html), (ii) Lempicka, 1971 and (iii) Vorosmarty et al. (1998).

\section{The Supplement related to this article is available online at https://doi.org/10.5194/hess-21-4115-2017- supplement.}

Competing interests. The authors declare that they have no conflict of interest.

Acknowledgements. We would like to thank Nadine Laporte, Innocent Liengola, Peter Umunay, Greg Fiske and Melanie Burr for help with data and literature search. We acknowledge the World Climate Research Program's Working Group on Coupled Modeling, which is responsible for CMIP, and we thank the climate modeling groups (Table 1) for producing and making their model output available. For CMIP, the US Department of Energy's Program for Climate Model Diagnosis and Intercomparison provided coordinating support and led development of software infrastructure in partnership with the Global Organization for Earth System Science Portals. We gratefully acknowledge the efforts of three anonymous reviewers who made thoughtful comments that 
substantially improved the manuscript. This work was supported in part by the facilities and staff of the Yale University Faculty of Arts and Sciences High Performance Computing Center and by the National Science Foundation under grant CNS 08-21132 that partially funded acquisition of the facilities.

Edited by: Lixin Wang

Reviewed by: three anonymous referees

\section{References}

Adams, W. M., Goudie, A., and Orme, A. R.: The physical geography of Africa, Oxford University Press, Oxford, New York, 1996.

Aloysius, N., Sheffield, J., Saiers, J. E., Li, H., and Wood, E. F.: Evaluation of historical and future simulations of precipitation and temperature in Central Africa from CMIP5 climate models, J. Geophys. Res.-Atmos., 121, 130-152, https://doi.org/10.1002/2015JD023656, 2016 (data available at: http://hydrology.princeton.edu/data.php).

Alsdorf, D., Beighley, E., Laraque, A., Lee, H., Tshimanga, R., O'Loughlin, F., Mahé, G., Dinga, B., Moukandi, G., and Spencer, R. G. M.: Opportunities for hydrologic research in the Congo Basin, Rev. Geophys., 54, 378-409, 2016.

Arnold, J. G., Srinivasan, R., Muttiah, R. S., and Williams, J. R.: Large area hydrologic modeling and assessment part I: Model development, J. Am. Water Resour. Assoc., 34, 73-89, 1998.

Balas, N., Nicholson, S. E., and Klotter, D.: The relationship of rainfall variability in West Central Africa to sea-surface temperature fluctuations, Int. J. Climatol., 27, 1335-1349, 2007.

Bartholomé, E. and Belward, A. S.: GLC2000: A new approach to global land cover mapping from Earth observation data, Int. J. Remote Sens., 26, 1959-1977, 2005.

Beighley, R. E., Ray, R. L., He, Y., Lee, H., Schaller, L., Andreadis, K. M., Durand, M., Alsdorf, D. E., and Shum, C. K.: Comparing satellite derived precipitation datasets using the Hillslope River Routing (HRR) model in the Congo River Basin, Hydrol. Process., 25, 3216-3229, 2011.

Bruinsma, J.: World agriculture: towards 2015/2030: An FAO perspective, Earthscan/James \& James, London, UK, 520 pp., 2003.

Bultot, F. and Griffiths, J. F.: The Equatorial Wet Zone, in: Climate of Africa, edited by: Griffiths, J. F., Elsevier Publishing Company, Amsterdam, 259-291, 1972.

Burney, J. A., Naylor, R. L., and Postel, S. L.: The case for distributed irrigation as a development priority in sub-Saharan Africa, P. Natl. Acad. Sci. USA, 110, 12513-12517, 2013.

Center for International Earth Science Information Network (CIESIN) Columbia University, United Nations Food and Agriculture Programme (FAO), and C.I.d.A.T. (CIAT): Gridded Population of the World: Future Estimates (GPWFE), Center for International Earth Science Information Network (CIESIN) Columbia University, New York, USA, 2005.

Collier, P., Conway, G., and Venables, T.: Climate change and Africa, Oxford Rev. Econ. Policy, 24, 337-353, 2008.

DeFries, R. and Rosenzweig, C.: Toward a whole-landscape approach for sustainable land use in the tropics, P. Natl. Acad. Sci. USA, 107, 19627-19632, 2010.
Doherty, J.: PEST: Model-independent Parameter Estimation, User Manual, 5th Edn., Watermark Numerical Computing, Brisbane, Australia, 2004.

FAO/IIASA: Harmonized World Soil Database (version 1.1), Food and Agricultural Organization and IIASA, Rome, Italy and Laxenburg, Austria, 2009.

Faramarzi, M., Abbaspour, K. C., Ashraf Vaghefi, S., Farzaneh, M. R., Zehnder, A. J. B., Srinivasan, R., and Yang, H.: Modeling impacts of climate change on freshwater availability in Africa, J. Hydrol., 480, 85-101, 2013.

Gibbs, H. K., Ruesch, A. S., Achard, F., Clayton, M. K., Holmgren, P., Ramankutty, N., and Foley, J. A.: Tropical forests were the primary sources of new agricultural land in the 1980s and 1990s, P. Natl. Acad. Sci. USA, 107, 16732-16737, 2010.

Giorgetta, M. A., Jungclaus, J., Reick, C. H. Legutke, S., Bader, J., Böttinger, M., Brovkin, V., Crueger, T., Esch, M., Fieg, K., Glushak, K., Gayler, V., Haak, H., Hollweg, H.-D., Ilyina, T., Kinne, S., Kornblueh, L., Matei, D., Mauritsen, T., Mikolajewicz, U., Mueller, W., Notz, D., Pithan, F., Raddatz, T., Rast, S., Redler, R., Roeckner, E., Schmidt, H., Schnur, R., Segschneider, J., Six, K. D. Stockhause, M., Timmreck, C., Wegner, J., Widmann, H., Wieners, K.- H., Claussen, M., Marotzke, J., and Stevens, B.: Climate and carbon cycle changes from 1850 to 2100 in MPI-ESM simulations for the coupled model intercomparison project phase 5, J. Adv. Model. Earth Syst., 5, 572597, 2013.

Global Runoff Data Center: Long-Term Mean Monthly Discharges and Annual Characteristics of GRDC Stations, available at: http: //www.bafg.de/GRDC/EN/Home/homepage_node.html (last access: 22 March 2010), Federal Institute of Hydrology, Koblenz, Germany, 2011.

Good, P., Jones, C., Lowe, J., Betts, R., and Gedney, N.: Comparing tropical forest projections from two generations of Hadley Centre Earth System models, HadGEM2-ES and HadCM3LC, J. Climate, 26, 495-511, https://doi.org/10.1175/jcli-d-11-00366.1, 2012.

Hansen, M. C., Roy, D. P., Lindquist, E., Adusei, B., Justice, C. O., and Altstatt, A.: A method for integrating MODIS and Landsat data for systematic monitoring of forest cover and change in the Congo Basin, Remote Sens. Environ., 112, 2495-2513, 2008.

Hastenrath, S.: Interannual variability and annual cycle: Mechanisms of circulation and climate in the tropical Atlantic sector, Mon. Weather Rev., 112, 1097-1107, 1984.

Hirst, A. C. and Hastenrath, S.: Diagnostics of hydrometeorological anomalies in the Zaire (Congo) basin, Q. J. Roy. Meteorol. Soc., 109, 881-892, 1983.

Hulme, M., Doherty, R., Ngara, T., New, M., and Lister, D.: African Climate Change: 1900-2100, Clim. Res., 17, 145-168, 2001.

IPCC: Summary for policymakers, in: Climate Change 2014: Impacts, Adaptation, and Vulnerability. Part A: Global and Sectoral Aspects, Contribution of Working Group II to the Fifth Assessment Report of the Intergovernmental Panel on Climate Change Rep., Intergovernmental Panel on Climate Change, Cambridge, UK, 1-32, 2014.

Jungclaus, J. H., Fischer, N., Haak, H., Lohmann, K., Marotzke, J., Matei, D., Mikolajewicz, U., Notz, D., and von Storch, J. S.: Characteristics of the ocean simulations in the Max Planck Institute Ocean Model (MPIOM) the ocean component of the MPI- 
Earth system model, J. Adv. Model. Earth Syst., 5, 422-446, 2013.

Knutti, R. and Sedlacek, J.: Robustness and uncertainties in the new CMIP5 climate model projections, Nat. Clim. Change, 3, 369373, 2013

Krysanova, V. and White, M.: Advances in water resources assessment with SWAT - an overview, Hydrolog. Sci. J., 60, 771-783, 2015.

Laporte, N. T., Goetz, S. J., Justice, C. O., and Heinicke, M.: A new land cover map of central Africa derived from multi-resolution, multi-temporal AVHRR data, Int. J. Remote Sens., 19, 35373550, 1998.

Lee, H., Beighley, R. E., Alsdorf, D., Jung, H. C., Shum, C. K., Duan, J., Guo, J., Yamazaki, D., and Andreadis, K.: Characterization of terrestrial water dynamics in the Congo Basin using GRACE and satellite radar altimetry, Remote Sens. Environ., 115, 3530-3538, 2011.

Legates, D. R. and McCabe Jr., G. J.: Evaluating the use of "Goodness-of-Fit" measures in hydrologic and hydroclimatic model validation, Water Resour. Res., 35, 233-241, 1999.

Lehner, K., Verdin, K., and Jarvis, A.: New Global Hydrography Derived from Spaceborne Elevation Data, Eos. Trans. AGU, 89, 93-94, https://doi.org/10.1029/2008EO100001, 2008.

Lempicka, M.: Bilan hydrique du bassin du fleuve Zaire, Rep., Office National de la Recherche et du Development, Kinshasa, DRC, 1971.

Li, H., Sheffield, J., and Wood, E. F.: Bias correction of monthly precipitation and temperature fields from Intergovernmental Panel on Climate Change AR4 models using equidistant quantile matching, J. Geophys. Res.-Atmos., 115, D10101, https://doi.org/10.1029/2009jd012882, 2010.

Lund, B., Snell, E., Easton, D., and De Beer, A.: Aqueduct to link Central Africa with Southern Africa? A brief outline, Civil Eng., 15, 4-8, 2007.

L'vovich, M. I.: World water resources and their future, American Geophysical Union, Washington, DC, 1979.

Malhi, Y. and Grace, J.: Tropical forests and atmospheric carbon dioxide, Trends Ecol. Evol., 15, 332-337, 2000.

Masson, D. and Knutti, R.: Climate model genealogy, Geophys. Res. Lett., 38, L08703, https://doi.org/10.1029/2011gl046864, 2011.

Matungulu, K.-M.: Characterization and fertility evaluation of some major soil groups from Zaire (Central Africa), North Carolina State University, Raleigh, North Carolina, 1992.

Meehl, G. A., Washington, W. M., Arblaster, J. M., Hu, A., Teng, H., Kay, J. E., Gettelman, A., Lawrence, D. M., Sanderson, B. M., and Strand, W. G.: Climate change projections in CESM1(CAM5) compared to CCSM4, J. Climate, 26, 62876308, 2013.

Mitchell, T. D. and Jones, P. D.: An improved method of constructing a database of monthly climate observations and associated high-resolution grids, Int. J. Climatol., 25, 693-712, 2005.

Molden, D. (Ed.): Water for food, water for life: A comprehensive assessment of water management in agriculture, Earthscan and International Water Management Institute, London, UK and Colombo, Sri Lanka, 645 pp., 2007.

Moriasi, D. N., Arnold, J. G., Van Liew, M. W., Bingner, R. L., Harmel, R. D., and Veith, T. L.: Model evaluation guidelines for systematic quantification of accuracy in watershed simulations, Trans. ASABE, 50, 885-900, 2007.

Moss, R. H., Edmonds, J. A., Hibbard, K. A., Manning, M. R., Rose, S. K., van Vuuren, D. P., Carter, T. R., Emori, S., Kainuma, M., Kram, T., Meehl, G. A., Mitchell, J. F. B., Nakicenovic, N., Riahi, K., Smith, S. J., Stouffer, R. J., Thomson, A. M., Weyant, J. P., and Wilbanks, T. J.: The next generation of scenarios for climate change research and assessment, Nature, 463, 747-756, 2010.

Munzimi, Y. A., Hansen, M. C., Adusei, B., and Senay, G. B.: Characterizing Congo Basin Rainfall and Climate Using Tropical Rainfall Measuring Mission (TRMM) Satellite Data and Limited Rain Gauge Ground Observations, J. Appl. Meteorol. Clim., 54, 541-555, 2014.

Nash, J. E. and Sutcliffe, J. V.: River flow forecasting through conceptual models, Part I. A discussion of principles, J. Hydrol., 10, 282-290, 1970.

Nathan, R. J. and McMahon, T. A.: Evaluation of automated techniques for base flow and recession analyses, Water Resour. Res., 26, 1465-1473, 1990.

Neitsch, S. L., Arnold, J. G., Kiniry, J. R., and Williams, J. R.: Soil Water Assessment Tool, Theoretical Documentation, Version 2009, Rep. 406, Texas Water Resources Institute, Texas A \& M University, Temple, Texas, 647 pp., 2011.

Niang, I., Ruppel, O. C., Abdrabo, M. A., Essel, A., Lennard, C., Padgham, J., and Urquhart, P.: Africa, in: Climate Change 2014: Impacts, Adaptation, and Vulnerability. Part B: Regional Aspects, Contribution of Working Group II to the Fifth Assessment Report of the Intergovernmental Panel of Climate Change, edited by: Barros, V. R., Field, C. B., Dokken, D. J., Mastrandrea, M. D., Mach, K. J., Bilir, T. E., Chatterjee, M., Ebi, K. L., Estrada, Y. O., Genova, R. C., Girma, B., Kissel, E. S., Levy, A. N., MacCracken, S., Mastrandrea, P. R., and White, L. L., Cambridge University Press, Cambridge, UK and New York, NY, USA, 1115, 2014.

Nicholson, S. E.: The nature of rainfall variability over Africa on time scales of decades to millenia, Global Planet. Change, 26, 137-158, 2000.

Nicholson, S. E. and Grist, J. P.: The seasonal evolution of the atmospheric circulation over West Africa and Equatorial Africa, J. Climate, 16, 1013-1030, 2003.

Nicholson, S. E. and Dezfuli, A. K.: The Relationship of Rainfall Variability in Western Equatorial Africa to the Tropical Oceans and Atmospheric Circulation. Part I: The Boreal Spring, J. Climate, 26, 45-65, 2013.

Nilsson, C., Reidy, C. A., Dynesius, M., and Revenga, C.: Fragmentation and Flow Regulation of the World's Large River Systems, Science, 308, 405-408, 2005.

Randall, D. A., Wood, R. A., Bony, S., Colman, R., Fichefet, T., J., Fyfe, Kattsov, V., Pitman, A., Shukla, J., Srinivasan, J., Stouffer, R. J., Sumi, A., and Taylor, K. E.: Cilmate Models and Their Evaluation, in: Climate Change 2007: The Physical Science Basis, Contribution of Working Group I to the Fourth Assessment Report of the Intergovernmental Panel on Climate Change, edited by: Solomon, S., Qin, D., Manning, M., Chen, Z., Marquis, M., Averyt, K. B., Tignor, M., and Miller, H. L., Cambridge University Press, Cambridge, UK and New York, NY, USA, 2007.

Rodell, M., Houser, P. R., Jambor, U., Gottschalck, J., Mitchell, K., Meng, C. J., Arsenault, K., Cosgrove, B., Radakovich, J., Bosilovich, M., Entin, J. K., Walker, J. P., Lohmann, D., and Toll, 
D.: The global land data assimilation system, B. Am. Meteorol. Soc., 85, 381-394, 2004.

Runge, J.: The Congo River, Central Africa, in: Large Rivers: Geomorphology and Management, edited by: Gupta, A., John Wiley, Chichester, England, 293-309, 2007.

Salathé Jr., E. P., Mote, P. W., and Wiley, M. W.: Review of scenario selection and downscaling methods for the assessment of climate change impacts on hydrology in the United States pacific northwest, Int. J. Climatol., 27, 1611-1621, 2007.

Samba, G., Nganga, D., and Mpounza, M.: Rainfall and temperature variations over Congo-Brazzaville between 1950 and 1998, Theor. Appl. Climatol., 91, 85-97, 2008.

Schuol, J., Abbaspour, K. C., Yang, H., Srinivasan, R., and Zehnder, A. J. B.: Modeling blue and green water availability in Africa, Water Resour. Res., 44, W07406, https://doi.org/10.1029/2007wr006609, 2008.

Sheffield, J., Goteti, G., and Wood, E. F.: Development of a 50-year high-resolution global dataset of meteorological forcings for land surface modeling, J. Climate, 19, 3088-3111, https://doi.org/10.1175/JCLI3790.1, 2006 (data available at: http://hydrology.princeton.edu/data/pgf/Readme.txt).

Showers, K.: Congo River's Grand Inga hydroelectricity scheme: Linking environmental history, policy and impact, Water Hist., 1, 31-58, 2009.

Siam, M. S., Demory, M.-E., and Eltahir, E. A. B.: Hydrological cycles over the Congo and Upper Blue Nile Basins: Evaluation of general circulation model simulations and reanalysis products, J. Climate, 26, 8881-8894, 2013.

Taylor, K. E., Stouffer, R., and Meehl, G.: An overview of CMIP5 and the experiment design, B. Am. Meteorol. Soc., 93, 485-498, 2012.

Teutschbein, C. and Seibert, J.: Bias correction of regional climate model simulations for hydrological climate-change impact studies: Review and evaluation of different methods, J. Hydrol., 456457, 12-29, 2012.

Thompson, J. R., Green, A. J., and Kingston, D. G.: Potential evapotranspiration-related uncertainty in climate change impacts on river flow: an assessment for the Mekong River Basin, J. Hydrol., 510, 259-279, 2014.

Trambauer, P., Maskey, S., Winsemius, H., Werner, M., and Uhlenbrook, S.: A review of continental scale hydrological models and their suitability for drought forecasting in (sub-Saharan) Africa, Phys. Chem. Earth Pt. A/B/C, 66, 16-26, 2013.

Tshimanga, R. M. and Hughes, D. A.: Climate change and impacts on the hydrology of the Congo Basin: The case of the northern sub-basins of the Oubangui and Sangha Rivers, Phys. Chem. Earth Pt. A/B/C, 50-52, 72-83, 2012.

Tshimanga, R. M. and Hughes, D. A.: Basin-scale performance of a semidistributed rainfall-runoff model for hydrological predictions and water resources assessment of large rivers: The Congo River, Water Resour. Res., 50, 1174-1188, 2014.

UNEP: Water Issues in the Democratic Republic of the Congo: Challenges and Opportunities Rep., United Nations Environment Program, Nairobi, Kenya, 2011. van Griensven, A., Ndomba, P., Yalew, S., and Kilonzo, F. Critical review of SWAT applications in the upper Nile basin countries, Hydrol. Earth Syst. Sci., 16, 3371-3381, https://doi.org/10.5194/hess-16-3371-2012, 2012.

Vetter, T., Reinhardt, J., Flörke, M., van Griensven, A., Hattermann, F., Huang, S., Koch, H., Pechlivanidis, I. G., Plötner, S., Seidou, O., Su, B., Vervoort, R. W., and Krysanova, V.: Evaluation of sources of uncertainty in projected hydrological changes under climate change in 12 large-scale river basins, Climatic Change, 141, 419-433, 2016.

Voldoire, A., Sanchez-Gomez, E., Salas y Mélia, D., Decharme, B., Cassou, C., Sénési, S., Valcke, S., Beau, I., Alias, A., Chevallier, M., Déqué, M., Deshayes, J., Douville, H., Fernandez, E., Madec, G., Maisonnave, E., Moine, M. P., Planton, S., SaintMartin, D., Szopa, S., Tyteca, S., Alkama, R., Belamari, S., Braun, A., Coquart, L., and Chauvin, F.: The CNRM-CM5.1 global climate model: Description and basic evaluation, Clim. Dynam., 40, 2091-2121, 2012.

Vorosmarty, C. J., Fekete, B. M., and Tucker, B. A.: Global River Discharge, 1807-1991, Version 1.1 (RivDIS), Data set, Oak Ridge National Laboratory Distributed Active Archive Center, Oak Ridge, Tennessee, USA, available at: http://www.daac.ornl. gov (last access: 1 August 2017), 1998.

Washington, R., James, R., Pearce, H., Pokam, W. M., and Moufouma-Okia, W.: Congo Basin rainfall climatology: Can we believe the climate models?, Philos. T. Roy. Soc. B, 368, 20120296, https://doi.org/10.1098/rstb.2012.0296, 2013.

Weaver, C. P., Lempert, R. J., Brown, C., Hall, J. A., Revell, D., and Sarewitz, D.: mproving the contribution of climate model information to decision making: the value and demands of robust decision frameworks, Wires Clim. Change, 4, 39-60, 2013.

Wohl, E., Barros, A., Brunsell, N., Chappell, N. A., Coe, M., Giambelluca, T., Goldsmith, S., Harmon, R., Hendrickx, J. M. H., Juvik, J., McDonnell, J., and Ogden, F.: The hydrology of the humid tropics, Nat. Clim. Change, 2, 655-662, 2012.

Wood, A. W., Leung, L. R., Sridhar, V., and Lettenmaier, D. P.: Hydrologic implications of dynamical and statistical approaches to downscaling climate model outputs, Climatic Change, 62, 189216, 2004.

World Bank Group: World Development Indicators, World Bank Publications, Washington, DC, 2014.

World Food Program: Democratic Republic of Congo Rep., World Food Program, Rome, Italy, 113 pp., 2014.

Yang, Y., Donohue, R. J., McVicar, T. R., Roderick, M. L., and Beck, H. E.: Long-term $\mathrm{CO}_{2}$ fertilization increases vegetation productivity and has little effect on hydrological partitioning in tropical rainforests, J. Geophys. Res.-Biogeo., 121, 2125-2140, 2016.

Yukimoto, S., Noda, A., Kitoh, A., Hosaka, M., Yoshimura, H., Uchiyama, T., Shibata, K., Arakawa, O., and Kusunoki, S.: Present-day climate and climate sensitivity in the Meteorological Research Institute coupled GCM version 2.3 (MRI-CGCM2.3), J. Meteorol. Soc. Jpn., 84, 333-363, 2006. 